УДК 616.12-008.331.1:577.115.3:541.4:57.084.1

DOI: 10.15587/2519-4852.2018.141411

\title{
RESEARCH OF 1,3-OXAZOLE-4-IL-PHOSPHONIC ACID DERIVATIVE ON THE CONTENT OF FATTY ACIDS OF LIPIDS IN RATS WITH ARTERIAL HYPERTENSION
}

\author{
(C) K. Matskevych
}

Кількість хворих з артеріальною гіпертензією (АГ) продовжує збільшуватись. Суттєвим негативним наслідком артеріальної гіпертензії є структурні, метаболічні та функціональні порушення у тканинах міокарду, судин та інших органів, зокрема зміна вмісту жирних кислот (ЖК) та їх співвідношення.

Мета роботи - дослідити зміну жирнокислотного складу ліпідів сироватки крові та тканин щурів $з$ артеріальною гіпертензією під дією нової оригінальної сполуки - похідного 1,3-оксазол-4-іл-фосфонової кислоти (скорочена назва - похідне оксазолу).

Матеріали та методи. Дослідження проводили на білих статевозрілих щурах. Артеріальну гіпертензію моделювали шляхом сольового навантаження - сольового пиття (1\% розчин натрію хлориду) з вільним доступом до нього впродовж 21 доби. Тваринам з 14-ї доби вводили похідне оксазолу в дозі 25 мг/кг внутрішньоочеревинно, один раз на добу, щоденно, протягом 7 діб. Вміст ЖК ліпідів відцентрифугованої сироватки крові та гомогенізованих у 0,9\% фізіологічному розчині $\mathrm{NaCl}$ тканин визначали за допомогою газохроматографічного аналізу.

Результати та ӥх обговорення. Введення похідного оксазолу на фоні підвищеного артеріального тиску у шурів достовірно не впливало на суму НЖК та ННЖК в сироватці крові на відміну від групи щурів з АГ за рахунок тенденції до відновлення вмісту стеаринової кислоти, проте змінений вміст лінолевої та арахідонової кислот практично не відрізнявся від значень останніх в контрольній крупі за даних умов експерименту. В аорті спостерігалось відновлення вмісту пальмітинової, стеаринової, лінолевої та арахідонової кислот. В сериі встановлено зміну вмісту лінолевої та арахідонової кислот у зворотньому напрямку порівняно з контрольною групою.

Висновки. Введення похідного оксазолу в дозі 25 мг/кг (ED $\left.D_{50}\right)$ внутрішньоочеревинно один раз на добу протягом 7 днів при одночасному моделюванні артеріальної гіпертензї иляхом сольового навантаження виілому не викликало негативних змін та призводило до відновлення ліпідних показників НЖК, ННЖК та ПНЖК

Ключові слова: артеріальна гіпертензія, жирні кислоти,похідне 1,3-оксазол-4-іл-фосфонової кислоти, похідне оксазолу, щури

\section{Introduction}

Today, the global pharmaceutical market presents a wide range of antihypertensive drugs. However, the number of patients with arterial hypertension $(\mathrm{AH})$ continues to increase. This disease causes annually about $12.8 \%$ of deaths in the world and leads to a significant deterioration in the quality of life of patients due to the severity of the consequences of its ineffective treatment: myocardial infarction, stroke, chronic renal failure and peripheral arterial disease [1, 2]. The accelerated dynamics of hypertension is an urgent problem of modern medicine, which is exacerbated by demographic aging of the population and behavioural risk factors, including malnutrition, hypodynamia, and permanent stress conditions [3].

2. Formulation of the problem in a general way, the relevance of the theme and its connection with important scientific and practical issues

Despite the presence of a significant arsenal of drugs with a different mechanism of action, the effectiveness of antihypertensive therapy remains low. In particular, in Ukraine, this figure is only $8.1 \%$ in rural areas and $18.7 \%$ in the urban population, which requires further detailed study of the pathogenesis of this disease and the search for new compounds to achieve the target blood pressure levels by acting directly on the target, which is the cause of development arterial hypertension [4, 5].
3. Analysis of recent studies and publications in which a solution of the problem are described and to which the author refers

Substantial negative effects of arterial hypertension are structural, metabolic and functional disorders in the tissues of the myocardium, vessels and other organs, in particular, changes in the content of fatty acids (FA) and their ratios $[6,7]$. Changes in lipid metabolism in hypertension are associated with a decrease in the consumption of fatty acids by the body due to increased absorption and an imbalance between glucose and FA in mitochondria [8]. It is known that hypertension rats in blood plasma most change the content of arachidonic, palmitic, linoleic, pentadecanoic and margaric acids [9]. Therefore, an important task of modern antihypertensive therapy is the search for molecules and the development of new antihypertensive drugs, which can not only normalize blood pressure, but also correct these pathological changes.

4. The field of research considering the general problem, which is described in the article

The derivative of 1,3-oxazole-4-yl-phosphonic acid (abbreviated name - oxazole derivative) is a novel, original compound, which, according to the results of previous experimental studies, in vitro and in vivo has a vasodilating effect and is promising for further study as a 
low-toxic antihypertensive agent, but its influence on the fatty acid composition of lipids in the blood to this time was not investigated $[10,11]$.

\section{Formulation of goals (tasks) of article}

The aim of the work was to investigate the changes in the fatty acid composition of blood serum lipids and tissues of rats with arterial hypertension under the action of oxazole derivatives.

\section{Presentation of the main research material (methods and objects) with the justification of the results}

Materials and methods. The studies were conducted on white, sexually mature rats with an average weight of $181.8 \pm 3.54 \mathrm{~g}$. Animal rearing and care was carried out in accordance with the European Union Directive 2019/10/63 EU on the protection of vertebrate animals used for experimental and other scientific purposes and, accordingly, to the Law of Ukraine No. 3447IV "On the Protection of Animals from Cruel Treatment" $[12,13]$.

Arterial hypertension $(\mathrm{AH})$ was modelled with salt loading - salt drink (1\% solution of sodium chloride) with free access to it for 21 days [14]. The mean blood pressure level in non-sarcotised rats was recorded by sphygmomanometric method using a specialized cuff with a pulse sensor mounted on the rat's tail and an analysis of the periodicity of blood flow oscillations at the UgoBasile installation (Italy, 2005).

With the random sampling technique, rats were divided into 3 groups of 7 individuals in each. Group 1 included intact rats. Group 2 (blank) includes rats, which formed a model of stable AH during 21 days by salt loading. Group 3 includes rats with elevated blood pressure of $8 \%$ and above at 14 days after the start of salt loading. Animals of this group from the 14th day were given a dose of $25 \mathrm{mg} / \mathrm{kg}$ intraperitoneally, once, daily for 7 days. This group of animals is formed to determine the effect of 1,3-oxazole-4-yl-phosphonic derivative in order to prevent the development of hypertension or decrease the degree of hypertension.

The rats were decapitated with subsequent extirpation of the heart, aorta, liver, kidneys and blood collection. The content of liquid lipids of centrifuged blood serum and homogenized in $0.9 \%$ saline $\mathrm{NaCl}$ tissue was determined by gas chromatographic analysis according to the generally accepted method [15]. The peaks of fatty acids were identified by comparing with the time maintenance of the peaks of standard FA. An assay of the ratio of fatty acids of lipids in \% was carried out by the method of normalizing the peaks of the peaks of ethylenic derivatives of FA [16].

Changes in fatty acid composition of serum lipids were evaluated by the definition of the quantitative content of the 9 most informative FA: myristic $\mathrm{C}_{14: 0}$, pentadecane $\mathrm{C}_{15: 0}$, palmitinic $\mathrm{C}_{16: 0}$, margaric $\mathrm{C}_{17: 0}$, stearic $\mathrm{C}_{18: 0}$, amounting to SFA, and oleic $\mathrm{C}_{18: 1}$, linoleic $\mathrm{C}_{18: 2}$, linolenic $\mathrm{C}_{18: 3}$, arachidonic $\mathrm{C}_{20: 4}$, amounting to the MUFA. Lin- oleic $\mathrm{C}_{18: 2}$, linolenic $\mathrm{C}_{18: 3}$ and arachidonic $\mathrm{C}_{20: 4} \mathrm{FA}$ belong to the sum of polyunsaturated fatty acids (PUFA) and are defined as irreplaceable [15].

Statistical data was processed using the BioStat 2009 v 5.8.4 licensing program (produced by Analyst Soft). To compare mean values of the samples, a simple Student's coefficient was used, or a two-sample t-test with different dispersions (heteroscedastic). Changes in indicators were considered statistically significant at a significance level of more than $95 \%(\mathrm{P}<0.05)$.

Results of the research. Studies have shown that in the modelling of persistent arterial hypertension by the salt load in Group 2, the fatty acid composition of blood serum lipids and tissues of the investigated organs significantly changed in comparison with the group of normotensive intact rats (Tab.1). In particular, serum levels of stearic acid increased by $28.4 \%(\mathrm{p}<0.05)$, resulting in an increase in the amount of SFA by $11.2 \%$ (p <0.05). At the same time, the content of arachidonic acid increased by almost 5 times ( $\mathrm{p}<0.05$ ), but the amount of UFA and PUFA decreased in the form of a tendency due to a decrease in the content of linoleic acid. In the aorta, an increase in the content of myristic (by 8 times, $\mathrm{p}<0.05$ ) and palmithinic acid $(40.4 \%, \mathrm{p}<0.05)$ and reduction in the content of stearic acid $(17.8 \%, \mathrm{p}<0.05)$, linoleic $(28.9 \%, \mathrm{p}<0.05)$ and arachidone $(25.4 \%, \mathrm{p}<0.05)$ acids. Accordingly, an increase in the amount of SFA and a reduction in the amount of UFA, PUFA in the aorta were noted. In the heart, only a decrease in the content of linoleic and an increase in the content of arachidonic acids was observed, respectively, by $25.8 \%$ ( $\mathrm{p}<0.05)$ and $16.9 \%(\mathrm{p}<0.05)$, and in the liver the increase in the content of oleic $(17.1 \%, \mathrm{p}<0.05)$, linoleic acids (by $29.1 \%, \mathrm{p}<0,05)$ and reduction of arachidonic acid content (by 28,6\%, p<0.05). At the same time, in the kidneys, a $22.2 \%(\mathrm{p}<0.05)$ decrease in the amount of SFA was observed due to myristic and palmitic acid and a corresponding increase in the UFA value by $16.7 \%$ ( $p<0.05)$ due to oleic, linoleic and arachidonic acids .

From Tabl. 2, it can be seen that the administration of the oxazole derivative in the background of elevated blood pressure in rats did not significantly affect the amount of SFA and UFA in serum, unlike the group of rats with hypertension due to the tendency to restore the stearic acid content, but the changed content of linoleic and arachidonic acids was virtually nonexistent it differed from the values of the latter in the blank group under the given experimental conditions. Restoration of the content of stearic, linoleic and arachidonic acids in the aorta and reduction of the palmitic acid content to the baseline level was observed. In the heart, the change in the content of linoleic and arachidonic acids in the reverse direction compared with the blank group was established. Thus, the content of linoleic acid, by contrast, was higher by $14.4 \%$ ( $\mathrm{p}<0.05)$, and the content of arachidonic acid was lower by $18.4 \%(p<0.05)$ compared to normalizing rats. In the kidneys and the liver, all the lipid fatty acid composition was normalized. 
Fatty acid composition of rat lipid tissues and serum in experimental arterial hypertension, \% (M $\pm \mathrm{m}, \mathrm{n}=7)$

\begin{tabular}{|c|c|c|c|c|c|c|c|c|c|c|}
\hline \multirow[b]{2}{*}{$\begin{array}{c}\text { Nomenclature of } \\
\text { FA }\end{array}$} & \multicolumn{2}{|c|}{ blood serum } & \multicolumn{2}{|c|}{ aorta } & \multicolumn{2}{|c|}{ heart } & \multicolumn{2}{|c|}{ kidneys } & \multicolumn{2}{|c|}{ liver } \\
\hline & $\begin{array}{l}\text { Group } \\
\text { No.2 }\end{array}$ & $\begin{array}{c}\text { Group } \\
\text { No.1 }\end{array}$ & $\begin{array}{l}\text { Group } \\
\text { No.2 }\end{array}$ & $\begin{array}{c}\text { Group } \\
\text { No.1 }\end{array}$ & $\begin{array}{l}\text { Group } \\
\text { No.2 }\end{array}$ & $\begin{array}{c}\text { Group } \\
\text { No.1 }\end{array}$ & $\begin{array}{l}\text { Group } \\
\text { No.2 }\end{array}$ & $\begin{array}{c}\text { Group } \\
\text { No.1 }\end{array}$ & $\begin{array}{l}\text { Group } \\
\text { No.2 } \\
\end{array}$ & $\begin{array}{l}\text { Group } \\
\text { No.1 }\end{array}$ \\
\hline Myristic C14:0 & $0.3 \pm 0.1$ & $0.3 \pm 0.1$ & $3.3 \pm 0.5^{*}$ & $0.4 \pm 0.1$ & $0.6 \pm 0.1$ & $0.4 \pm 0.1$ & $1.1 \pm 0.1 *$ & $3.1 \pm 0.5$ & $0.4 \pm 0.1$ & $0.3 \pm 0.1$ \\
\hline Pentadecane C15:0 & $0.4 \pm 0.1$ & $0.2 \pm 0.1$ & $0.3 \pm 0.1$ & $0.5 \pm 0.1$ & $1.6 \pm 0.3$ & $1.6 \pm 0.5$ & $0.4 \pm 0.1$ & $0.4 \pm 0.1$ & $0.4 \pm 0.1$ & $0.3 \pm 0.1$ \\
\hline Palmitinic C16:0 & $26.4 \pm 1.3$ & $25.3 \pm 1.5$ & $38.6 \pm 1.3^{*}$ & $27.5 \pm 1.5$ & $19.5 \pm 1.5$ & $18.3 \pm 1.5$ & $21.2 \pm 1.0 *$ & $29.4 \pm 1.5$ & $19.1 \pm 0.1$ & $21.3 \pm 1.3$ \\
\hline Margaric C17:0 & $0.4 \pm 0.1$ & $0.3 \pm 0.1$ & $0.3 \pm 0.1$ & $0.4 \pm 0.1$ & $0.6 \pm 0.1$ & $0.4 \pm 0.1$ & $0.4 \pm 0.1$ & $0.4 \pm 0.1$ & $0.4 \pm 0.1$ & $0.3 \pm 0.1$ \\
\hline Stearic C18:0 & $11.3 \pm 1.0 *$ & $8.8 \pm 1.0$ & $11.1 \pm 1.0 *$ & $13.5 \pm 1.0$ & $9.3 \pm 0.5$ & $9.0 \pm 1.0$ & $10.2 \pm 0.5$ & $9.5 \pm 0.5$ & $6.6 \pm 0.5$ & $6.1 \pm 0.5$ \\
\hline Oleic C18:1 & $15.2 \pm 1.0$ & $15.6 \pm 1.3$ & $18.4 \pm 0.6$ & $18.7 \pm 0.7$ & $15.3 \pm 0.7$ & $13.9 \pm 1.0$ & $14.8 \pm 0.7 *$ & $17.2 \pm 1.0$ & $15.1 \pm 1.0^{*}$ & $12.9 \pm 1.0$ \\
\hline Linoleic C18:2 & $44.2 \pm 1.5^{*}$ & $49.0 \pm 1.5$ & $23.1 \pm 1.0 *$ & $32.5 \pm 1.5$ & $22.1 \pm 1.0^{*}$ & $29.8 \pm 1.5$ & $24.8 \pm 0.5^{*}$ & $28.1 \pm 1.5$ & $35.9 \pm 1.5^{*}$ & $27.8 \pm 1.5$ \\
\hline Linolenic C18:3 & $0.4 \pm 0.1$ & $0.2 \pm 0.1$ & $0.3 \pm 0.1$ & $0.5 \pm 0.1$ & $0.6 \pm 0.1$ & $0.4 \pm 0.1$ & $0.4 \pm 0.1$ & $0.4 \pm 0.1$ & $0.4 \pm 0.1$ & $0.5 \pm 0.1$ \\
\hline Arachidonic C18:4 & $1.4 \pm 0.5^{*}$ & $0.3 \pm 0.1$ & $4.4 \pm 0.5^{*}$ & $5.9 \pm 0.8$ & $30.5 \pm 1.0 *$ & $26.1 \pm 1.5$ & $26.7 \pm 1.0^{*}$ & $11.3 \pm 1.0$ & $21.7 \pm 1.5^{*}$ & $30.4 \pm 1.5$ \\
\hline$\sum$ SFA & $38.8 \pm 1.8^{*}$ & $34.9 \pm 1.8$ & $53.6 \pm 1.5^{*}$ & $42.3 \pm 1.6$ & $31.6 \pm 2.0$ & $29.7 \pm 1.8$ & $33.3 \pm 1.5^{*}$ & $42.8 \pm 2.0$ & $26.9 \pm 1.6$ & $28.3 \pm 1.8$ \\
\hline$\sum$ UFA & $61.2 \pm 1.8$ & $65.1 \pm 1.8$ & $46.4 \pm 1.5^{*}$ & $57.7 \pm 1.6$ & $68.5 \pm 2.0$ & $70.3 \pm 1.8$ & $66.5 \pm 1.5^{*}$ & $57.0 \pm 2.0$ & $73.1 \pm 1.6$ & $71.7 \pm 1.8$ \\
\hline$\sum$ PUFA & $46.0 \pm 1.5^{*}$ & $49.5 \pm 1.5$ & $27.8 \pm 1.3 *$ & $38.9 \pm 1.5$ & $53.2 \pm 1.8$ & $56.3 \pm 1.6$ & $51.7 \pm 1.3^{*}$ & $39.8 \pm 1.6$ & $58.0 \pm 1.3$ & $58.7 \pm 1.5$ \\
\hline
\end{tabular}

Note: $*-p<0.05$ relative to the intact group (group No. 1 )

Table 2

Influence of 1,3-oxazole-4-yl-phosphonic acid derivative on fatty acid composition of rat lipid tissues and serum in

\begin{tabular}{|c|c|c|c|c|c|c|c|c|c|c|}
\hline \multirow{2}{*}{$\begin{array}{c}\text { Nomenclature } \\
\text { of FA }\end{array}$} & \multicolumn{2}{|c|}{ blood serum } & \multicolumn{2}{|c|}{ aorta } & \multicolumn{2}{|c|}{ heart } & \multicolumn{2}{|c|}{ kidneys } & \multicolumn{2}{|c|}{ liver } \\
\hline & $\begin{array}{l}\text { Group } \\
\text { No. } 2\end{array}$ & $\begin{array}{l}\text { Group } \\
\text { No.1 }\end{array}$ & $\begin{array}{l}\text { Group } \\
\text { No.2 }\end{array}$ & $\begin{array}{l}\text { Group } \\
\text { No.1 }\end{array}$ & $\begin{array}{l}\text { Group } \\
\text { No.2 }\end{array}$ & & $\begin{array}{l}\text { Group } \\
\text { No.2 }\end{array}$ & $\begin{array}{l}\text { Group } \\
\text { No.1 }\end{array}$ & $\begin{array}{l}\text { Group } \\
\text { No.2 }\end{array}$ & $\begin{array}{l}\text { Group } \\
\text { No.1 }\end{array}$ \\
\hline Myristic C14:0 & $0.5 \pm 0.1$ & $0.3 \pm 0.1$ & $3.1 \pm 0.5^{*}$ & $0.4 \pm 0.1$ & $0.4 \pm 0.1$ & $0.4 \pm 0.1$ & $2.4 \pm 0.5$ & $3.1 \pm 0.5$ & $0.3 \pm 0.1$ & $0.3 \pm 0.1$ \\
\hline $\begin{array}{l}\text { Pentadecane } \\
\text { C15:0 }\end{array}$ & $0.5 \pm 0.1$ & $0.2 \pm 0.1$ & $0.4 \pm 0.1$ & $0.5 \pm 0.1$ & $1.1 \pm 0.5$ & $1.6 \pm 0.5$ & $0.4 \pm 0.1$ & $0.4 \pm 0.1$ & $0.3 \pm 0.1$ & $0.3 \pm 0.1$ \\
\hline $\begin{array}{l}\text { Palmitinic } \\
\text { C16:0 }\end{array}$ & $28.3 \pm 1.0$ & $25.3 \pm 1.5$ & $30.1 \pm 1.5$ & $27.5 \pm 1.5$ & $17.4 \pm 1.0$ & $18.3 \pm 1.5$ & $24.6 \pm 1.0^{*}$ & $29.4 \pm 0.1$ & $20.8 \pm 1.0$ & $21.3 \pm 1.3$ \\
\hline $\begin{array}{c}\text { Margaric } \\
\text { C17:0 }\end{array}$ & $0.5 \pm 0.1$ & $0.3 \pm 0.1$ & $0.4 \pm 0.1$ & $0.4 \pm 0.1$ & $0.4 \pm 0.1$ & $0.4 \pm 0.1$ & $0.4 \pm 0.1$ & $0.4 \pm 0.1$ & $0.3 \pm 0.1$ & $0.3 \pm 0.1$ \\
\hline Stearic C18:0 & $10.9 \pm 0.5$ & $8.8 \pm 1.0$ & $14.0 \pm 1.0$ & $13.5 \pm 1.0$ & $8.4 \pm 1.0$ & $9.0 \pm 0.1$ & $10.8 \pm 0.5$ & $9.5 \pm 0.5$ & $8.4 \pm 0.7$ & $6.1 \pm 0.5$ \\
\hline Oleic C18:1 & $14.8 \pm 0.6$ & $15.6 \pm 1.3$ & $18.1 \pm 1.0$ & $18.7 \pm 0.7$ & $16.3 \pm 0.5$ & $13.9 \pm 1.0$ & $19.2 \pm 0.8$ & $17.2 \pm 1.0$ & $14.5 \pm 1.0$ & $12.9 \pm 1.0$ \\
\hline Linoleic C18:2 & $42.2 \pm 1.0^{*}$ & $49.0 \pm 1.5$ & $28.0 \pm 1.5^{*}$ & $32.5 \pm 1.5$ & $34.1 \pm 1.0 *$ & $29.8 \pm 1.5$ & $31.4 \pm 0.5$ & $28.1 \pm 1.5$ & $30.1 \pm 1.3$ & $27.8 \pm 1.5$ \\
\hline $\begin{array}{c}\text { Linolenic } \\
\text { C18:3 }\end{array}$ & $0.6 \pm 0.1^{*}$ & $0.2 \pm 0.1$ & $0.4 \pm 0.1$ & $0.5 \pm 0.1$ & $0.4 \pm 0.1$ & $0.4 \pm 0.1$ & $0.4 \pm 0.1$ & $0.4 \pm 0.1$ & $0.4 \pm 0.1$ & $0.5 \pm 0.1$ \\
\hline $\begin{array}{c}\text { Arachidonic } \\
\text { C18:4 }\end{array}$ & $1.5 \pm 0.5^{*}$ & $0.3 \pm 0.1$ & $5.5 \pm 0.5$ & $5.9 \pm 0.8$ & $21.3 \pm 1.0 *$ & $26.1 \pm 1.5$ & $10.3 \pm 1.0$ & $11.3 \pm 1.0$ & $24.9 \pm 1.5$ & $30.4 \pm 1.5$ \\
\hline$\sum \mathrm{SFA}$ & $40.7 \pm 1.5$ & $34.9 \pm 1.8$ & $48.0 \pm 1.8^{*}$ & $42.3 \pm 1.6$ & $27.7 \pm 2.0$ & $29.7 \pm 1.8$ & $38.6 \pm 1.5$ & $42.8 \pm 2.0$ & $30.1 \pm 1.5$ & $28.3 \pm 1.8$ \\
\hline$\sum$ UFA & $59.1 \pm 1.5$ & $65.1 \pm 1.8$ & $52.0 \pm 1.8$ & $57.7 \pm 1.6$ & $72.1 \pm 2.0$ & $70.3 \pm 1.8$ & $61.3 \pm 1.5$ & $57.0 \pm 2.0$ & $69.9 \pm 1.5$ & $71.7 \pm 1.8$ \\
\hline$\sum$ PUFA & $44.3 \pm 1.3^{*}$ & $49.5 \pm 1.5$ & $33.9 \pm 1.5^{*}$ & $38.9 \pm 1.5$ & $55.8 \pm 1.8$ & $56.3 \pm 1.6$ & $42.1 \pm 1.3$ & $39.8 \pm 1.6$ & $55.4 \pm 1.3$ & $58.7 \pm 1.5$ \\
\hline
\end{tabular}

Discussion of results. The established fact of increasing the amount of SFA in the kidneys compared with the blank group after the administration of the 1,3oxazole-4-yl-phosphonic acid derivative may indicate the ability of the compound to stabilize cell membranes and inhibit free radical oxidation during the development of modulation-induced arterial hypertension inositol lipid cycle and signal system of the cell [17].

The effect of the oxazole derivative on the increase of arachidonic acid content by $25.0 \%(\mathrm{p}<0.05)$ in comparison with hypertensive rats in the aorta may be related to one of the mechanisms of vasodilating effect of the test compound, since arachidonic acid acts as a precursor in the synthesis of prostaglandin E2 (PGE2), which, in turn, interacts with receptors of type EP2, causes vasodilation [18]. At the same time, it is logical to increase the content of linoleic acid in the aorta as a precursor to the synthesis of arachidone. On the other hand, a decrease in the content of the latter in the heart and kidneys after the introduction of the derivative of oxazole may indicate the restorative ability of the test compound to reduce lipid peroxidation in the abovementioned tissues. A similar effect was found in $\beta$-blockers that exhibit cardioprotective and nephroprotective effects [9, 19].

7. Conclusions from the conducted research and prospects for further development of this field

1. Conducted studies showed a pronounced effect of 1,3-oxazole-4-yl-phosphonic acid derivative on fatty acids of serum lipids of blood and tissues of rats with elevated blood pressure in the modelling of arterial hypertension by salt loading.

2. The introduction of the test compound at a dose of $25 \mathrm{mg} / \mathrm{kg}\left(\mathrm{ED}_{50}\right)$ intraperitoneally once daily for 7 days with simultaneous simulation of arterial hypertension by salt load did not cause any adverse changes in general and led to the restoration of lipid parameters of SFA, UFA and PUFA.

3. The established fact of the influence of the derivative of oxazole on the composition of FA lipids is the basis for further study of its mechanisms of action with a possible prospect of studying as an antihypertensive drug. 


\section{References}

1. World Health Organization. Global status report on noncommunicable diseases 2010. Geneva: WHO, 2010.

2. Klinicheskie ispytaniya lekarstvennyh sredstv i farmakonadzor v Ukraine // Mater. nauchno-prak. seminara 1-2 iyunya 2001 g. Kyiv: Aviacenna, 2001. 128 p.

3. World Health Organization. A global brief on hypertension 2013. Geneva: WHO, 2013.

4. Unification of the protocol of extrinsic medical assistance. Hypertonic crisis. URL: http://moz.gov.ua/nakazi-moz

5. Slozhnye voprosy lecheniya arterial'noy gipertenzii: vliyanie povyshennoy chastoty serdechnyh sokrashcheniy i soputstvuyushchih zabolevaniy na vybor antigipertenzivnoy terapii v praktike kardiologa i terapevta [Complex questions of treatment of arterial hypertension: the effect of increased heart rate and concomitant diseases on the choice of antihypertensive therapy in the practice of a cardiologist and therapist] / Arutyunov G. P. et. al. // Ration Pharmacother Cardiol. 2015. Vol. 11, Issue 1. P. $63-67$.

6. Popov V. V., Bulanov N. A., Ivanov G. G. Current target of antihypertensive therapy. Data from clinical trials. Part $1 / /$ Rational Pharmacotherapy in Cardiology. 2012. Vol. 8, Issue 1. P. 88-94. doi: https://doi.org/10.20996/1819-6446-2012-8-1-88-94

7. Zahorodniy M. I., Briuzghina T. S., Svintsytskyi A. S. Zminy zhyrnokyslotnoho spektru lipidiv u shchuriv zi spontannoiu arterialnoiu hipertenzieiu [Changes in the fatty acid spectrum of lipids in spontaneous arterial hypertension rats] // Sertse i sudyny. 2008. Issue 3. P. 80-84.

8. Talati M., Hemnes A. Fatty Acid Metabolism in Pulmonary Arterial Hypertension: Role in Right Ventricular Dysfunction and Hypertrophy // Pulmonary Circulation. 2015. Vol. 5, Issue 2. P. 269-278. doi: https://doi.org/10.1086/681227

9. Dovhan R. S. Zminy vmistu zhyrnykh kyslot v miokardi ta plazmi krovi shchuriv z arterialnoiu hipertenziieiu pry zastosuvanni antyhipertenzyvnykh zasobiv [Changes in the content of fatty acids in the myocardium and blood plasma of rats with arterial hypertension in the use of antihypertensive drugs] // Visnyk problem biolohiyi i medytsyny. 2014. Vol. 2, Issue 3. P. 130-134.

10. The study of acute toxicity of 1,3-oxazole-4-il-phosphonic acid derivative in intraperitoneal administration / Nizhenkovska I. V. et. al. // News of Pharmacy. 2018. Issue 1 (93). P. 43-48. doi: https://doi.org/10.24959/nphj.18.2186

11. Issledovanie vliyaniya proizvodnogo 1,3-oksazol-4-il-fosfonovoy kisloty na arterial'noe davlenie i serdechnyy ritm u krolikov [Investigation of the effect of the 1,3-oxazole-4-yl-phosphonic acid derivative on blood pressure and heart rate in rabbits] / Nizhenkovskaya I. V. et. al. // Recept. 2018. Vol. 21, Issue 1. P. 75-83.

12. European Convention for the Protection of Vertebrate Animals used for Experimental and Other Scientific Purposes. URL: http://conventions.coe.int/treaty/en/treaties/html/123.htm

13. Pro zakhyst tvaryn vid zhorstokoho povodzhennia. Zakon vid 21.02.2006 No. 3447-IV. Verkhovna Rada Ukrainy. URL: http://zakon4.rada.gov.ua/laws/show/3447-15

14. Badyal D. K., Lata H., Dadhich A. P. Animal models of hypertension and effect of drugs // Indian J. Pharmacol. 2003. Vol. 35, Issue 6. P. 349-362.

15. Vplyv antyhipertenzyvnykh ta metabolitropnykh preparativ na zhyrnokyslotnyi sklad lipidiv kardiomiotsytiv u shchuriv zi spontannoiu arterialnoiu hipertenzieiu [Influence of antihypertensive and metabolic drugs on fatty acids content of lipids in cardiomyocytes of rats with spontaneous hypertension] / Puzyrenko A. M. et. al. // Ukrainskyi biokhimichnyi zhurnal. 2013. Vol. 85, Issue 4. P. 67-74.

16. Vyvchennia diyi metabolitnykh preparativ na zhyrnokyslotnyi sklad lipidiv tkanyn shchuriv zi spontannoiu arterialnoiu hipertenzieiu [Investigations of metabolite drugs action on fatty acid composition of lipids in tissues of rats with spontaneous hypertension] / Dovhan R. S. et. al. // Visnyk VDNZU «Ukrainska medychna stomatolohichna akademiya». 2016. Vol. 16, Issue 1. P. 202-205.

17. Vplyv nikotynovoi kysloty ta kompleksu hermaniu z nikotynovoiu kyslotoiu (MIHU-1) na zhyrnokyslotnyi sklad lipidiv kardiomiotsytiv i hepatotsytiv shchuriv z eksperymentalnoiu khronichnoiu sertsevoiu nedostatnistiu [Effects of nicotinic acid and complex of germanium with nicotinic acid (MIGU-1) on lipid fatty acid composition of cardiomyocytes and hepatocytes in rats with experimental chronic heart failure] / Nizhenkovska I. V. et. al. // Farmakolohiya ta likarska toksykolohiya. 2015. Issue 1. P. 68-75.

18. Cohen M., Sztokalo J., Hinsch E. The antihypertensive action of arachidonic acid in the spontaneous hypertensive rat and its antagonism by anti-inflammatory agents // Life Sciences. 1973. Vol. 13, Issue 4. P. 317-325. doi: https://doi.org/10.1016/00243205(73)90223-3

19. Isoprostanes - important marker of the oxidative stress estimation in patients with chronic kidney disease / Renke M. et. al. // Pol. Merkur. Lekarski. 2013. Vol. 34, Issue 199. P. 14-17.

Рекомендовано до публікаиії д-ром мед. наук, професор Ніженковська I. В. Дата надходження рукопису 24.07.2018

Matskevych Kateryna, Assistant, Department of Pharmaceutical, Biological and Toxicological Chemistry, Bogomolets National Medical University, Shevchenka blvd., 13, Kyiv, Ukraine, 01601, Co-author of 6 articles in professional pharmaceutical journals, 2 utility model patents.

E-mail: kateryna.sedko@nmu.ua 